\title{
Ev Hanımlarının Fiziksel Aktivite Şiddeti ve Alanlarına Göre Enerji Harcaması, Adım Sayısı ve Oturma Süresi
}

\author{
Energy Expenditure according to Physical Activity Intensity and Domains, Step Count, \\ and Sitting Time in Housewives
}

\author{
${ }^{1}$ Serhat SAĞINÇ \\ ${ }^{1}$ Necip DEMIRCI \\ ${ }^{1}$ Ayda KARACA
}

${ }^{1}$ Hacettepe Üniversitesi Spor Bilimleri Fakültesi Rekreasyon Bölümü Fiziksel Aktivite ve Sağlık Anabilim Dalı

\section{Yazışma Adresi \\ Corresponding Address:}

Doç. Dr. Ayda KARACA

ORCID: 0000-0002-3189-2385

Hacettepe Üniversitesi

Spor Bilimleri Fakültesi

Rekreasyon Bölümü

Fiziksel Aktivite ve Sağlık Anabilim Dalı

E-posta: aydakaraca@gmail.com

Geliş Tarihi (Received): 18.03.2020

Kabul Tarihi (Accepted): 03.05.2020

\section{öz}

Bu çalışmanın amacı Ankara ilinde ikamet eden ev hanımlarının farklı fiziksel aktivite (FA) şiddetlerine ve alanlarına göre harcadıkları enerji, adım sayısı ve oturma sürelerinin yaş, medeni durum, eğitim ve gelir düzeylerine göre incelenmesidir. Araştırmaya 18-65 yaşları arasında toplam 311 ev hanımı katılmışır. Tüm katılımcıların enerji harcamaları ve oturma süreleri Uluslararası Fiziksel Aktivite Anketi-Uzun Form (UFAA-UF) ile değerlendirilmiş, 60 ev hanımının adım sayısı ActiGraph wGT3X-BT ile ölçülmüştür. Verilerin analizinde normal dağılan verilerin ortalamaları arasındaki farkı incelemek için t testi ve Tek Yönlü Varyans Analizi kullanılmıştır. Normal dağılmayan verilerin ortalamaları arasındaki farkın anlamlılığını test etmek için Mann-Whitney U testi ve Kruskal Wallis Varyans Analizi uygulanmıştır. Ev hanımlarının orta şiddetli aktiviteler için harcadığı enerjinin (MET-dk/hafta), yürüyüş ve yüksek şiddetli aktivitelerden fazla (sırasıyla: $1410.01 \pm 818.73 ; 710.66 \pm 677.17 ; 81.80 \pm 400.64$ ), ev aktiviteleri için harcadığı enerjinin, aktif ulaşım ve serbest zaman aktivitelerinden fazla olduğu (sırasıyla:1367.82 $\pm 838.90 ; \quad 502.64 \pm 416.45 ; \quad 332.00 \pm 605.86$ ) görülmüştür. Oturma süreleri $3546.55 \pm 672.65 \mathrm{dk} /$ hafta olarak bulunmuştur. UFAA-UF sonuçlarına göre ev hanımlarının \%2.3'ü düşük, \%64.6'sı orta ve \%33.1'i yüksek FA düzeyindedir. Ev hanımlarının \%95'i bir günde minimum 7500 adım, \%76.6'sı bir günde minimum 10000 adım atmıştır. Katılımcıların bir günde ortalama $12057.38 \pm 2787.34$ adım attığı saptanmıştır. Katılımcıların günlük ortalama adım sayıları bakımından yaş, medeni durum, eğitim ve gelir düzeylerine göre anlamlı düzeyde fark saptanmamıştır ( $p>0.05$ ). Sonuç olarak; çalışmaya katılan ev hanımlarının neredeyse tamamı orta ve yüksek şiddette fiziksel aktivite düzeyini, dörtte üçü önerilen düzeyde adım sayısını karşılamaktadır.

Anahtar Kelimeler: Fiziksel aktivite, Adım sayısı, Oturma süresi, Ev hanımları

\section{ABSTRACT}

The aim of this study was to investigate the physical activity, sitting time, and step count of housewives living in Ankara in terms of demographic parameters such as age, marital status, education level, and income level. Three-hundred eleven housewives aged 18-65 participated in this study. International Physical Activity QuestionnaireLong Form (IPAQ-LF) was used for estimating energy expenditure and sitting time for all participants. The step counts of 60 of 311 housewives were measured with ActiGraph wGT3X-BT. One-Way ANOVA or t-test was used for parametric data, and Mann Whitney $U$ test or Kruskal Wallis Variance Analysis were used for or nonparametric data. Housewives consumed more energy (MET-min/week) for moderate PA than both vigorous PA and walking (respectively: 1410.01 \pm 818.73 ; 710.66 $\pm 677.17 ; 81.80 \pm 400.64$ ), and also consumed more energy (MET-min/week) for household activities than both active transportation and leisure time (respectively: $1367.82 \pm 838.90 ; 502.64 \pm 416.45 ; 332.00 \pm 605.86$ ). The sitting time of housewives was $3546.55 \pm 672.65$ minutes per week. The percentage of low-level physical activity of participants was quite lower than moderate and vigorous physical activity levels (respectively: $2.3 \% ; 64.6 \% ; 33.1 \%$ ). The percentage of housewives whose step count more than 7500 (steps/day) was $95 \%$. 76.6\% of housewives met the recommended amount (10000 steps/day) of daily step count. The average number of daily steps of the participants was calculated $12507.38 \pm 2787.34$ steps. There was no statistically significant difference between the daily average number of steps with regard to age, marital status, income level, and education level ( $p>0.05)$. As a result, almost all housewives were found to be moderate and vigorous PA level, and three third of participants met the recommended level of step count.

Key Words: Physical activity, Step count, Sitting time, Housewives 


\section{GíRIŞ}

Fiziksel aktivite iskelet kasları tarafından gerçekleştirilen ve enerji harcamasına sebep olan herhangi bir vücut hareketi olarak tanımlanırken, sedanter davranış bireyin uyanık olduğu sırada 1.5 MET ve altında enerji harcamasını gerektiren davranışlar (örn: oturmak, yaslanmak, uzanmak vb.) olarak tanımlanmaktadır (World Health Organization [WHO], 2018). Teknolojinin ilerlemesi (ulaşım araçları, asansörler, uzaktan kumandalar, ev işlerinde kullanılan makineler) ile beraber inaktivitenin artması sağlı sorunlarını da beraberinde getirmektedir (Kim ve diğ., 2019). Önerilen düzeyde fiziksel olarak aktif olmak koroner arter hastalığı, hipertansiyon, inme, tip 2 diyabet, metabolik sendrom, osteoporoz, kolon ve meme kanseri, depresyon gibi bulaşıcı olmayan birçok kronik hastalıktan korunmada önemli rol oynamaktadır (Bullard ve diğ., 2019). Düzenli yapılan FA'nın sağlık yararlarının bilimsel olarak kanıtlanması üzerine Amerikan Spor Hekimliği Koleji (ACSM) 2007 yılında 'Egzersiz İlaçtır' kavramını gündeme getirmiştir (ACSM, 2018). Dolayısıyla FA düzeyinin belirlenmesiyle düşük düzeyde aktif olan bireylerin FA'ya yönlendirilmesi açısından FA düzeyi ve sedanter davranışın belirlenmesi oldukça önem taşımaktadır (Treuth ve diğ., 2005). Yetişkinlerde FA düzeyini belirlemeye ilişkin çalışmalara 1950'lerin sonlarına doğru başlandığı görülürken (Knuth ve Hallal, 2009), oturma süresinin 2000'li yılların başlarından itibaren çalışılmaya başlandığı görülmektedir (örn: oturma süresi 2002 yılından itibaren Eurobarometer araştırmasına dahil edilmiştir) (Milton ve diğ., 2015).

Dünya Sağlık Örgütü 18-64 yaş arası yetişkinlerde kardiyorespiratuvar, kassal uygunluk ve kemik sağlı̆̆ının gelişimi, bulaşıcı olmayan kronik hastalıkların gelişme riskinin azaltılması için haftada en az $150 \mathrm{dk}$ orta şiddetli aerobik fiziksel aktivite ya da $75 \mathrm{dk}$ şiddetli aerobik FA, ilave sağlık yararları için haftada en az $300 \mathrm{dk}$ orta şiddetli aerobik FA ya da 150 dk şiddetli aerobik FA önermektedir (WHO, 2010). Günlük adım sayıs1 5000'den az olan yetişkin bireyler sedanter olarak kabul edilmekte, aktif olarak nitelendirilmesi için günde en az 10000 adım atmaları önerilmektedir. (Tudor-Locke ve diğ., 2011). Yetişkinler için sedanter davranış rehberlerinde oturma süresinin azaltılması ve uzun süreli oturmaya ara verilmesi, diğer bir deyişle uzun oturma süresinin kesintiye uğratılması önerilmektedir (Stamatakis ve diğ., 2019).

Dünya Sağlık Örgütü'nün 2018-2030 Fiziksel Aktivite Küresel Eylem Planının dördüncü stratejik hedefinde (aktif sistemlerin oluşturulması) FA'nın artırılması ve sedanter sürenin azaltılmasına yönelik olarak ulusal ve yerel düzeyde yapılacak olan tarama çalışmalarında kullanılacak olan veri sistemlerinin iyileştirilmesi ve tüm yaş grupları ve FA alanlarını (iş, serbest zaman vb.) içermesi yer almaktadır (WHO, 2018). İş, okul, serbest zaman, ev işleri ve ulaşım aktiviteleri FA yoluyla enerji harcamasını artıran farklı FA alanlarıdır (Karaca, 2017). Bazı kanıtlar FA'nın farklı alanlarda kümelendiğini ve sosyo-demografik faktörlerle ilişkilendirildiğini ortaya koymaktadır (Del Duca ve diğ., 2015). Örneğin Brezilyalı yetişkinler üzerinde yapılan çalışmada serbest zamanlarında inaktif olan kadınlar iş aktivitelerinde de inaktif bulunurken, tüm kadınların \% 3.4'ü dört fiziksel aktivite alanında inaktif bulunmuştur (Del Duca ve diğ., 2015). Ayrıca Kirk ve Rhodes (2011)'in sistematik derlemesinde fiziksel olarak aktif olmayı gerektiren işlerde çalsşanların serbest zaman fiziksel aktiviteleri de yüksek bulunmuştur. Bunun yanı sıra ev ve bahçe işleri dahil olmak üzere ev içi aktiviteler, günlük enerji harcamasının büyük bir bölümünü oluşturabilmekte ve özellikle kadınların sağlığı üzerinde olumlu bir etkiye sahip olabilmektedir (Peeters ve diğ., 2014). Dolayısıyla iş aktivitelerinin hem sosyo-demografik değişkenler hem de diğer FA alanları açısından değerlendirilmesinin önemli olabileceği akla gelmektedir. Ev hanımları için FA alanları serbest zaman, ev ve ulaşım olarak ele alınabilir. Karaca (2008)'nın 19-59 yaşları arasındaki yetişkin bireylerde yaptığı çalışmada kadınların \%90'ının aktif ulaşımı tercih ettiği, \%26.72'sinin ise düzenli spor yaptığı belirtilmiştir. Middlekauff ve diğg. (2016)'nin çalışmasında 51-64 yaşları arasındaki Amerikalı kadınların orta ve yüksek şiddetli FA süresinin en yüksek olduğu FA alanı, serbest zaman aktiviteleridir. Kadınların yaklaşık dörtte birinin önerilen FA süresini 
karşılayamadığı belirtilmiş̧tir (Middlekauff ve diğ., 2016). Streb ve diğ. (2019)'nin çalışmasında yetişkinlerin ulaşım, ev işleri ve serbest zaman alanlarında inaktivite oranı (sırasıyla; \%85.9; \%58.4 ve 48.8) yüksek bulunmuştur.

Yaş, vücut kütle indeksi (VKİ), eğitim (Middlekauff ve diğ., 2016; Trost ve diğ., 2002), cinsiyet, medeni durum, psikolojik, bilişsel ve duygusal faktörler, sosyal ve kültürel faktörler (arkadaş ve aile desteği vb.), çevresel faktörler (yakın çevrenin güvenliği, iklim, trafik yoğunluğu vb.) fiziksel aktivite ile ilişkili faktörlerdir (Trost ve diğ., 2002). Biernat ve Piatkowska (2017)'nın araştırmasında çalışmayan kadınların yüksek şiddetli FA'lara katılım yüzdeleri daha düşük, Akdur ve diğ. (2003)'nin araştırmasında çalışmayan kadınların hem spor hem de oturularak yapılan ev aktiviteleri için harcadığı haftalık MET miktarı çalışan kadınlardan daha yüksek bulunmuştur. Çağlar ve diğ. (2009)'nin çalışmasında yaş ilerledikçe orta ve şiddetli aktivitelere katılım süresinin azaldığı, VKİ arttıkça düşük şiddetli aktivitelere katılım süresinin arttığı, eğitim düzeyi arttıkça düşük şiddetli aktivitelere katılım süresinin azaldığı belirtilmiştir.

Fiziksel aktiviteyi arttırmak sadece bireysel bir sorun olmayıp çok sektörlü, çok disiplinli ve kültürel açıdan uygun bir yaklaşımla toplumsal düzeyde de ele alınması gerekir (WHO, 2004; WHO, 2020). Bu bağlamda fiziksel inaktivitenin azaltılması ülkemizde hem Onuncu ve Onbirinci Kalkınma Planlarında hem de Sağlık Bakanlığı stratejileri içerisinde yer almaktadır. Sağlık Bakanlığı tarafından 2013 yılında yapılan 'Türkiye Kronik Hastalıklar ve Risk Faktörleri Sıklığı Çalışması'na göre Türkiye genelinde kadınların sadece \%13'ünün yeterli ölçüde FA yaptığı belirlenmiştir (Sağlık Bakanlığı [SB], 2013). FA'nın toplumda teşvik edilmesi Onuncu Kalkınma Planı (2014 -2018) içerisinde önemli yer tutmuş olup (Kalkınma Bakanlığı [KB], 2013), Onbirinci Kalkınma Planında (2019-2023) sağlıklı ve hareketli yaşam tarzının teşvik edilmesi hedeflerine yer verilmiştir (Türkiye Cumhuriyeti Cumhurbaşkanlığı Strateji ve Bütçe Başkanlığı [SBB], 2019). Dünya Sağlık Örgütü Avrupa Bölgesi İçin Fiziksel Aktivite Stratejisi 2016-2025'in öncelik alanı 3’te ele alındığı üzere ev hanımlarının da içerisinde bulunduğu zayıf gruplara erişmenin zor olduğu ve bu gruplara özel dikkat sarf edilmesi ve daha kapsamlı bir yaklaşım gerektiği belirtilmiştir (Dünya Sağlı Örgütü [DSÖ], 2016).

Ev hanımlarının FA'ya katılım düzeyinin objektif ve subjektif yöntemlerle belirlendiği bu çalışmanın bulgularının hem Sağlık Bakanlığı'nın stratejik hedefleri doğrultusunda yapılacak olan müdahale çalışmalarına hem de sonraki bilimsel araştırmalara temel oluşturacağı öngörülmektedir. Buradan hareketle, bu çalışmanın amacı Ankara ilinde ikamet eden 1865 yaşları arasındaki ev hanımlarının farklı FA şiddetleri ve alanlarına göre harcadıkları süre (dk/hafta), enerji (MET$\mathrm{dk} / \mathrm{hafta}$ ), adım sayıları ve oturma sürelerinin yaş, medeni durum, eğitim ve gelir düzeyine göre incelenmesidir.

\section{YÖNTEM}

Araştırma Grubu: Araştırma kapsamında Ankara'nın merkez ilçelerinden biri olan Keçiören ilçesinde ikamet eden, gelir getiren bir işte çalışmayan, hamile olmayan ve kronik bir rahatsızlığı olmayan 18-65 yaşları arasında 311 ev hanımı

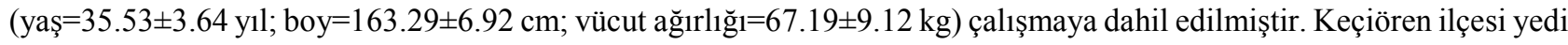
gösterge (yönetişim ve saydamlık, sosyal kapsama, ekonomik durum, eğitim, sağlık, sosyal yaşam, çevre ve ulaşım) kullanılarak dört sınıfın elde edildiği İnsani Gelişme Endeksi-İlçeler (İGE-İ) (2017)'e göre çok yüksek insani gelişme'nin bulunduğu ilçeler sınıfında yer almaktadır (INGEV, 2017; Şeker ve diğ., 2018). Çalışmaya başlamadan önce Hacettepe Üniversitesi Girişimsel Olmayan Klinik Araştırmalar Etik kurulundan (GO 18/808) etik kurul izni alınmıştır.

Veri Toplama Araçları: Bu çalışmada veri toplama aracı olarak Uluslararası Fiziksel Aktivite Anketi-Uzun Form, Actigraph wGT3X-BT, demografik bilgi formu kullanılmıştır.

Uluslararası Fiziksel Aktivite Anketi-Uzun Form (UFAA-UF): Ev hanımlarının FA düzeylerini, FA alanlarına göre enerji harcadıkları enerjiyi ve oturma sürelerini belirlemek amacıyla Craig ve arkadaşları tarafından 2003 yılında geliştirilen ve Türkiye'de geçerlilik ve güvenilirlik çalışması 2005 yılında Öztürk tarafından yapılan ve güvenilirlik katsayısı 0.64 , kriter geçerliliği 0.29 olarak tespit edilen UFAA-UF kullanılmıştır. UFAA-UF ile bireylerin ev, iş, ulaşım 
ve serbest zamanları sırasında yaptıkları şiddetli FA düzeyi, orta şiddetli FA düzeyi, yürüme süreleri, oturma süreleri ile FA düzeyleri belirlenmektedir.

Actigraph wGT3X-BT: Günlük adım sayısının objektif yöntemle belirlenmesinde ActiGraph wGT3X-BT akselerometre kullanılmıştır. Bu cihaz vektör büyüklüğü bakımından yüksek bir güvenirliğe (ICC $\geq 0.925)$ sahip olması nedeniyle pek çok çalışmada kullanılmıştır (Santos-Lozano ve diğ., 2013). Ağırlığı 19 gr olan akselerometrenin elastik bir kemer ile dominant el bileğine giyilmesi istenmiştir.

Demografik Bilgi Formu: Yaş, boy, vücut ağırlığı, medeni durum, gelir düzeyi gibi soruları içermektedir. Gelir düzeyini belirlemek için 'Sizce gelir ve gider durumunu düşündüğünüzde ailenizin ekonomik durumu nedir?' sorusu sorulmuştur. Bu soru kişinin gelir durumuna ilişkin kendi algısını yansıtmaktadır.

Verilerin Toplanması: Ev hanımlarının fiziksel aktivite alanlarına göre harcadıkları enerjinin ve oturma süresinin belirlenmesi amacıyla çalışmaya dahil edilen tüm katılımcılara UFAA-UF uygulanmıştır ( $\mathrm{n}=311)$. 311 katılımcıdan adım sayıları ölçülmeyen $251 \mathrm{ev}$ hanımı sadece bir kez ziyaret edilmiş ve demografik bilgi formu ve UFAA-UF uygulanmıştır. Çalışmaya katılmayı kabul eden $311 \mathrm{ev}$ hanımı içerisinden 60'ı adım sayılarının belirlenmesi için yedi gün süresince Actigraph wGT3X-BT giymiştir. Adım sayıları ölçülen ev hanımlarına yedi gün arayla iki ziyaret gerçekleştirilmiş, birinci ziyarette demografik bilgi formu uygulanmış, boy ve vücut ağırlığı ölçümü yapılmış ve akselerometreyi giymeleri istenmiştir. Sekizinci günde yapılan ikinci ziyarette ise akselerometre geri alınmış ve UFAA-UF uygulanmıştır. Araştırmanın veri toplama süreci 2019 yılı Nisan-Haziran aylarında tamamlanmıştır.

Uluslararası Fiziksel Aktivite Anketi-Uzun Form (UFAA-UF) ile Fiziksel Aktivite ve Oturma Sürelerinin Belirlenmesi: UFAA-UF toplam 311 ev hanımına görüşme yöntemiyle uygulanmıştır. Çalışmaya herhangi bir işte çalışmayan ev hanımları dahil edildiği için, UFAA- UF içeriğinde yer alan iş aktivitesi bölümü uygulanmamıştır. Araştırmanın bulgularını etkilememesi açısından son 7 günü her zamankinden farklı olan ev hanımlarının araştırmaya dahil edilmemesi amacıyla soru formuna 'Son 7 gününüz her zamankinden farklı mıdı?' sorusu eklenmiş olup bu soruya tüm ev hanımları 'hayır' cevabı vermiştir. UFAA-UF için toplam skor hesaplanırken tüm aktivite alanlarındaki süre (dakika) ve frekans (gün) değerleri belirlenmiştir. Bütün aktivitelerin değerlendirilmesinde her bir aktivitenin tek seferde en az 10 dk yapılıyor olması ölçüt alınmıştır. Süre (dk/gün), sıklık (gün/hafta) ve MET değeri çarpılarak "MET-dk/hafta" olarak bir değer elde edilmektedir. UFAA-UF kullanılarak MET-dk/hafta skorlarının hesaplanması ve FA düzeyinin kategorik olarak düşük, orta ve yüksek şeklinde sınıflandırılabilmesi için IPAQ Research Committe tarafindan 2005 yılında hazırlanan kılavuz kullanılmıştır (IPAQ Research Committee [IPAQ- RC], 2005).

ActiGraph wGT3X-BT Akselerometre ile Adım Sayısının Belirlenmesi: Çalışmaya dahil olan 60 ev hanımına evlerinde iki ziyaret gerçekleştirilmiştir. İlk ziyarette akselerometre cihazı ev hanımları tarafından giyilmeden önce ActiLife 6 yazılımı vasıtasıyla her bir katılımcı için ölçüm yapılacak zaman dilimi ve diğer gerekli bilgiler (cinsiyet, yaş, dominant el) cihazlara yüklenmiştir. Bu çalışmada beş saniyelik epok uzunluğu tercih edilmiştir. Bu düzenlemelerin yapılması ile akselerometreler kayıt yapmaya hazır konuma getirilmiş ve ev hanımlarından ActiGraph wGT3X-BT akselerometreyi yedi gün süreyle giymeleri istenmiştir. Sekizinci günde yapılan ikinci ziyaret sırasında akselerometreler araştırmacı tarafından geri alınmıştır. Cihazdan elde edilen veriler, Actilife 6 yazılımı kullanılarak Excel dosyası olarak kaydedilmiştir ve ev hanımlarının günlük ortalama adım sayıları hesaplanmıştır.

Bu çalışmada katılımcılardan 7 günlük veri elde edilmiştir. Verilerin analiz edilebilmesi için bir günde en az sekiz saatlik verinin kayıt altına alınmış olması gerekmektedir. Bu araştırmada akselerometrenin giyildiği süre içerisinde katılımcıların günlük yaşamlarının daha önceki doğal rutini içerisinde olması istenmiştir. Katılımcılara akselerometreyi gece uyurken çıkarmak zorunda olmadıkları ancak isterlerse çıkarabilecekleri ve çıkarmaları durumunda sabah uyanır 
uyanmaz tekrar giymeleri gerektiği ancak duş, yüzme gibi su ile temas gerektiren aktiviteler sırasında cihazın giyilmemesi gerektiği özellikle vurgulanmıştır.

ActiGraph wGT3X-BT cihazı ile edilen adım sayıları <5000 (sedanter), 5000 - 7499 (düşük aktif), 7500 - 9999 (biraz aktif), 10000 -12499 (aktif) ve >12500 (yüksek aktif) şeklinde sınıflandırılarak (Tudor-Locke ve Bassett, 2004) katılımcıların günlük ortalama adım sayıları değerlendirilmiştir.

Verilerin Analizi: Verilerin analizinde kullanılmış olan değişkenler için tanımlayıcı istatistikler ortalama ve standart sapma şeklinde gösterilmiştir. Değişkenlerin normallik testleri Kolmogorov-Smirnov testi ile yapılmıştır. Normal dağılım gösteren değişkenlerde farkların incelenmesi için t testi ve One-Way ANOVA, normal dağılım göstermeyen değişkenlerde farkların incelenmesi için Kruskal Wallis testi ve Mann-Whitney U testi uygulanmıştır. Kruskal Wallis testinde fark elde edilmesi durumunda farkın hangi gruptan kaynaklandığını saptamak için Mann Whitney U testi kullanılmıştır. İstatistiksel anlamlılık düzeyi $\mathrm{p}<0.05$ olarak kabul edilmiştir.

\section{BULGULAR}

Farklı FA şiddetlerine ve alanlarına göre harcanan enerjinin, oturma süresi ve adım sayılarının medeni durum, yaş, eğitim ve gelir düzeylerine göre incelendiği tablolar aşağıda verilmiştir.

Ev hanımlarının yüksek şiddetli FA, orta şiddetli FA ve yürüyüş ile aktif ulaşım, ev aktiviteleri ve serbest zaman için harcadığı süre (dk/hafta) ve enerji (MET-dk/hafta) Tablo 1'de verilmiştir.

Tablo 1. UFAA-UF verilerine göre farklı şiddette FA'lara ve farklı FA alanlarına harcanan enerji (MET-dk/hafta) ve süre $(\mathrm{dk} / \mathrm{hafta})(\mathrm{n}=311)$.

\begin{tabular}{|c|c|c|c|c|c|}
\hline & UFAA- & & Ort \pm Ss & Ortanca & Q25-Q75 \\
\hline \multirow{6}{*}{ 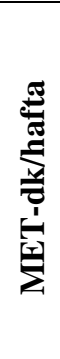 } & \multirow{3}{*}{$\begin{array}{l}\text { FA } \\
\text { Şiddeti }\end{array}$} & Yüksek & $81.80 \pm 400,64$ & 0.00 & $0.00-0.00$ \\
\hline & & Orta & $1410.01 \pm 818.73$ & 1260.00 & $900.00-1960.00$ \\
\hline & & Yürüyüş & $710.66 \pm 677.17$ & 495.00 & $297.00-990.00$ \\
\hline & \multirow{3}{*}{$\begin{array}{l}\text { FA } \\
\text { Alanı }\end{array}$} & Aktif Ulaşım & $502.64 \pm 416.45$ & 396.00 & $247.50-594.00$ \\
\hline & & Ev & $1367.82 \pm 838.90$ & 1260.00 & $780.00-1800.00$ \\
\hline & & Serbest Zaman & $332.00 \pm 605.86$ & 0.00 & $0.00-594.00$ \\
\hline \multirow{6}{*}{ 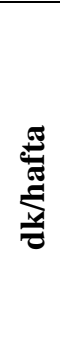 } & \multirow{3}{*}{$\begin{array}{l}\text { FA } \\
\text { Şiddeti }\end{array}$} & Yüksek & $10.22 \pm 50.08$ & 0.00 & $0.00-0.00$ \\
\hline & & Orta & $455.94 \pm 265.21$ & 420.00 & $270.00-600.00$ \\
\hline & & Yürüyüş & $215.35 \pm 205.20$ & 150.00 & $90.00-300.00$ \\
\hline & \multirow{3}{*}{$\begin{array}{l}\text { FA } \\
\text { Alanı }\end{array}$} & Aktif Ulaşım & $151.52 \pm 125.86$ & 120.00 & $75.00-180.00$ \\
\hline & & Ev & $445.88 \pm 270.86$ & 420.00 & $240.0-600.00$ \\
\hline & & Serbest Zaman & $84.11 \pm 144.80$ & 0.00 & $0.00-150.00$ \\
\hline
\end{tabular}

FA: Fiziksel Aktivite, Q25-Q75:1 ve 3. Çeyreklik

Ev hanımlarının orta şiddetli FA'lar için bir haftada harcadığı toplam süre (dk/hafta) ve toplam enerji (MET-dk/hafta), yüksek şiddetli FA'lar ve yürüyüş için harcadıkları enerjiden daha fazladır (Tablo 1). FA alanları dikkate alındığında ev aktiviteleri için bir haftada harcanan toplam süre (dk/hafta) ve toplam enerjinin (MET-dk/hafta), aktif ulaşım ve serbest zaman aktiviteleri için harcanandan daha fazla bulunmuştur (Tablo 1). Ev hanımlarının orta-yüksek şiddetli FA'lar için bir haftada harcadığı sürenin (466.94 dk/hafta) Dünya Sağlık Örgütü'nün önerisini karşıladığı görülmüştür. 
Ev hanımlarının yüksek şiddetli FA, orta şiddetli FA ve yürüyüş aktiviteleri için bir haftada harcadığı enerjinin (METdk/hafta) bazı demografik değişkenlere göre karşılaştırılması Tablo 2'de verilmiştir.

Tablo 2. Ev hanımlarının farklı şiddetteki FA'lar için harcadıkları enerjinin (MET-dk/hafta) bazı demografik değişkenlere göre karşılaştırılması

\begin{tabular}{|c|c|c|c|c|c|c|c|}
\hline \multirow{2}{*}{$\begin{array}{l}\text { Fiziksel } \\
\text { Aktivite } \\
\text { Alanları }\end{array}$} & \multirow{2}{*}{\multicolumn{2}{|c|}{ Demografik Bilgiler }} & \multicolumn{3}{|c|}{ UFAA-UF (MET-dk/hafta) } & \multirow{2}{*}{$\begin{array}{c}Z \\
\text { ya da } \\
\chi^{2} \\
\end{array}$} & \multirow[b]{2}{*}{$\mathbf{p}$} \\
\hline & & & $\mathbf{n}$ & Ort & Ss & & \\
\hline \multirow{11}{*}{ 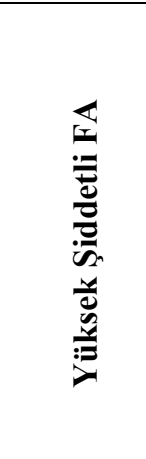 } & & $18-25$ & 64 & 75.00 & 322.49 & \multirow{4}{*}{14.890} & \multirow{4}{*}{$0.002^{1}$} \\
\hline & Yaș & $26-35$ & 122 & 169.18 & 585.18 & & \\
\hline & & $36-45$ & 61 & 0.00 & 0.00 & & \\
\hline & & $46-65$ & 64 & 0.00 & 0.00 & & \\
\hline & & İlk ve ortaokul & 113 & 0.00 & 0.00 & \multirow{3}{*}{15.102} & \multirow{3}{*}{$0.001^{1}$} \\
\hline & Egitim & Lise & 103 & 93.20 & 460.07 & & \\
\hline & & Üniversite & 95 & 166.73 & 532.15 & & \\
\hline & Medeni & Evli & 192 & 72.50 & 368.58 & \multirow{2}{*}{-0.553} & \multirow{2}{*}{$0.580^{2}$} \\
\hline & Durum & Bekar & 119 & 96.80 & 448.80 & & \\
\hline & Gelir & Orta ve altı & 143 & 13.42 & 97.74 & \multirow{2}{*}{-2.622} & \multirow{2}{*}{$0.009^{2}$} \\
\hline & Düzeyi & Yüksek & 168 & 140.00 & 531.43 & & \\
\hline \multirow{11}{*}{ 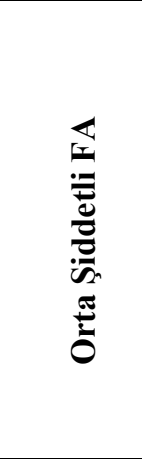 } & & $18-25$ & 64 & 1026.79 & 722.87 & \multirow{4}{*}{34.266} & \multirow{4}{*}{0.000} \\
\hline & Yaș & $26-35$ & 122 & 1517.04 & 784.80 & & \\
\hline & & $36-45$ & 61 & 1720.00 & 825.77 & & \\
\hline & & $46-65$ & 64 & 1293.75 & 815.68 & & \\
\hline & & İlk ve ortaokul & 113 & 1493.09 & 845.81 & \multirow{3}{*}{8.47} & \multirow{3}{*}{$0.014^{1}$} \\
\hline & Egitim & Lise & 103 & 1557.13 & 839.44 & & \\
\hline & & Üniversite & 95 & 1151.68 & 702.95 & & \\
\hline & Medeni & Evli & 192 & 1628.17 & 831.77 & \multirow{2}{*}{-6.353} & \multirow{2}{*}{$0.000^{2}$} \\
\hline & Durum & Bekar & 119 & 1058.02 & 662.40 & & \\
\hline & Gelir & Orta ve altı & 143 & 1580.10 & 919.90 & \multirow{2}{*}{-2.984} & \multirow{2}{*}{$0.003^{2}$} \\
\hline & Düzeyi & Yüksek & 168 & 1265.23 & 692.03 & & \\
\hline \multirow{11}{*}{ : } & & $18-25$ & 64 & 661.03 & 600.65 & \multirow{4}{*}{18.407} & \multirow{4}{*}{0.000} \\
\hline & Yaș & $26-35$ & 122 & 792.81 & 632.29 & & \\
\hline & & $36-45$ & 61 & 752.50 & 761.89 & & \\
\hline & & $46-65$ & 64 & 563.83 & 731.97 & & \\
\hline & & İlk ve ortaokul & 113 & 660.14 & 776.27 & \multirow{3}{*}{10.372} & \multirow{3}{*}{0.005} \\
\hline & Egitim & Lise & 103 & 744.10 & 628.34 & & \\
\hline & Duzeyı & Üniversite & 95 & 734,51 & 600,84 & & \\
\hline & Medeni & Evli & 192 & 636.45 & 657.13 & -3160 & $0002^{2}$ \\
\hline & Durum & Bekar & 119 & 830.40 & 694.48 & -3.100 & $0.002^{2}$ \\
\hline & Gelir & Orta ve alt 1 & 143 & 671.88 & 688.20 & -1608 & $0090^{2}$ \\
\hline & Düzeyi & Yüksek & 168 & 743.67 & 660.92 & -1.098 & $0.090^{-}$ \\
\hline
\end{tabular}

${ }^{1}$ Kruskal Wallis testi ile analiz edilmiştir.

${ }^{2}$ Mann-Whitney U testi ile analiz edilmiştir.

Ev hanımlarının yürüyüş, orta şiddetli ve yüksek şiddetli FA'lar için harcadıkları enerji miktarı yaş grupları arasında farklılık göstermiştir (p<0.05). 18-25 ve 26-35 yaş gruplarındaki ev hanımlarının yüksek şiddetteki FA'lar için harcadıkları enerji, 36-45 ve 46-65 yaş gruplarındakilerin harcadığından fazla bulunurken ( $\mathrm{p}<0.05), 18-25$ yaş grubundaki ev hanımlarının orta şiddetli FA'lar için harcadıkları enerji, diğer tüm yaş gruplarındaki ev hanımlarınınkinden daha az bulunmuştur $(\mathrm{p}<0.05)$. 46-65 yaş grubundaki ev hanımlarının yürüyüş için harcadıkları enerji, diğer yaş grubundaki ev hanımlarının harcadıklarından az bulunmuştur $(\mathrm{p}<0.05)$. İlk ve ortaokul mezunu olan ev hanımlarının yüksek şiddetli FA'lar ve yürüyüş için harcadıkları enerji, hem lise hem de üniversite mezunu olanlardan anlamlı düzeyde azdır ( $\mathrm{p}<0.05$ ). Üniversite mezunlarının orta şiddetli FA'ya katılım sırasında harcadıkları enerji, hem ilk ve ortaokul hem de lise 
mezunlarından anlamlı düzeyde azdır $(\mathrm{p}<0.05)$. Evli olan ev hanımlarının orta şiddetli FA'lar için harcadıkları enerji, bekar olanların harcadığından fazla $(\mathrm{p}<0.05)$, bekar ev hanımlarının yürüyüş için harcadıkları enerji evli olanlardan fazla bulunmuştur $(\mathrm{p}<0.05)$. Gelir durumu orta ve altında olan ev hanımlarının orta şiddetli FA'lar için harcadıkları enerji, gelir durumu yüksek olan ev hanımlarının harcadıklarından fazla $(\mathrm{p}<0.05)$, gelir durumu yüksek olan ev hanımlarının yüksek şiddetli FA'lar için harcadıkları enerji ise gelir durumu orta ve altında olan ev hanımlarının harcadıklarından fazladır $(\mathrm{p}<0.05)$.

Ev hanımlarının yaş, medeni durum, eğitim ve gelir düzeyleri bakımından farklı FA alanları için harcadıkları enerjinin (MET-dk/hafta) karşılaştırılması Tablo 3'de verilmiştir.

Tablo 3. Ev hanımlarının bazı demografik özellikler bakımından bazı FA alanlarına harcadıkları enerjinin karşılaştırılması

\begin{tabular}{|c|c|c|c|c|c|c|c|}
\hline \multirow{2}{*}{$\begin{array}{l}\text { Fiziksel } \\
\text { Aktivite } \\
\text { Alanları }\end{array}$} & \multirow{2}{*}{\multicolumn{2}{|c|}{ Demografik Bilgiler }} & \multicolumn{3}{|c|}{ UFAA-UF (MET-dk/hafta) } & \multirow{2}{*}{$\begin{array}{c}Z \\
\text { ya da } \\
\chi 2\end{array}$} & \multirow[b]{2}{*}{$\mathbf{p}$} \\
\hline & & & $\mathbf{n}$ & Ort & Ss & & \\
\hline \multirow{11}{*}{ 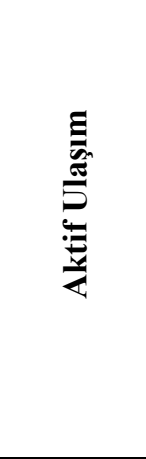 } & \multirow{4}{*}{ Yaş } & $18-25$ & 64 & 444.84 & 238.35 & \multirow{4}{*}{11.247} & \multirow{4}{*}{$0.010^{1}$} \\
\hline & & $26-35$ & 122 & 545.42 & 425.06 & & \\
\hline & & $36-45$ & 61 & 539.31 & 366.79 & & \\
\hline & & $46-65$ & 64 & 443.95 & 556.59 & & \\
\hline & \multirow{3}{*}{$\begin{array}{l}\text { Eğgitim } \\
\text { düzeyi }\end{array}$} & İlk ve ortaokul & 113 & 504.63 & 521.504 & \multirow{3}{*}{3.311} & \multirow{3}{*}{$0.191^{1}$} \\
\hline & & Lise & 103 & 510.16 & 346.21 & & \\
\hline & & Üniversite & 95 & 492.12 & 343.02 & & \\
\hline & \multirow{2}{*}{$\begin{array}{l}\text { Medeni } \\
\text { Durum }\end{array}$} & Evli & 192 & 497.82 & 454.89 & \multirow{2}{*}{-1.105} & \multirow{2}{*}{$0.269^{2}$} \\
\hline & & Bekar & 119 & 510.42 & 347.24 & & \\
\hline & \multirow{2}{*}{$\begin{array}{l}\text { Gelir } \\
\text { Düzeyi }\end{array}$} & Orta ve alt1 & 143 & 508.82 & 498.85 & \multirow{2}{*}{-1.324} & \multirow{2}{*}{$0.186^{2}$} \\
\hline & & Yüksek & 168 & 497.38 & 332.08 & & \\
\hline \multirow{11}{*}{ 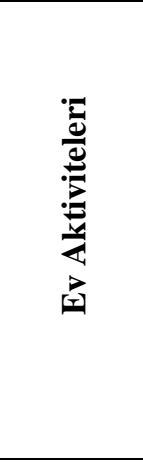 } & \multirow{4}{*}{ Yaş } & $18-25$ & 64 & 929.29 & 738.68 & \multirow{4}{*}{39.554} & \multirow{4}{*}{$0.000^{1}$} \\
\hline & & $26-35$ & 122 & 1473.44 & 808.26 & & \\
\hline & & $36-45$ & 61 & 1710.16 & 829.97 & & \\
\hline & & $46-65$ & 64 & 1278.75 & 817.29 & & \\
\hline & \multirow{3}{*}{$\begin{array}{l}\text { Ĕgitim } \\
\text { Düzeyi }\end{array}$} & İlk ve ortaokul & 113 & 1484.60 & 848.73 & \multirow{3}{*}{21.667} & \multirow{3}{*}{$0.000^{1}$} \\
\hline & & Lise & 103 & 1522.96 & 851.60 & & \\
\hline & & Üniversite & 95 & 1060.73 & 733.18 & & \\
\hline & \multirow{2}{*}{$\begin{array}{l}\text { Medeni } \\
\text { Durum }\end{array}$} & Evli & 192 & 1613.80 & 836.44 & \multirow{2}{*}{-7.149} & \multirow{2}{*}{$0.000^{2}$} \\
\hline & & Bekar & 119 & 970.96 & 677.56 & & \\
\hline & Gelir & Orta ve altı & 143 & 1557.16 & 931.72 & -3334 & $0001^{2}$ \\
\hline & Düzeyi & Yüksek & 168 & 1206.66 & 715.11 & -3.334 & $0.001^{-}$ \\
\hline & & $18-25$ & 64 & 388.68 & 557.77 & & \\
\hline & Yaş & $26-35$ & 122 & 460.17 & 725.00 & 26001 & $0 \Omega 0$ \\
\hline & & $36-45$ & 61 & 233.03 & 510.07 & 20.901 & $0.000^{2}$ \\
\hline Е & & $46-65$ & 64 & 134.88 & 386.18 & & \\
\hline స్ & & İlk ve ortaokul & 113 & 164.00 & 449.19 & & \\
\hline 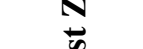 & EgitIm & Lise & 103 & 361.32 & 675.98 & 34.948 & $0.000^{1}$ \\
\hline : & Duzey & Üniversite & 95 & 500,06 & 640,99 & & \\
\hline छั & Medeni & Evli & 192 & 225.50 & 562.46 & -5604 & $0000^{2}$ \\
\hline & Durum & Bekar & 119 & 503.84 & 635.63 & -5.604 & $0.000^{2}$ \\
\hline & Gelir & Orta ve altı & 143 & 199.42 & 435.22 & -4.342 & $0.000^{2}$ \\
\hline & Düzeyi & Yüksek & 168 & 444.86 & 701.75 & -4.342 & \\
\hline
\end{tabular}

${ }^{1}$ Kruskal Wallis testi ile analiz edilmiştir.

${ }^{2}$ Mann-Whitney U testi ile analiz edilmiştir.

46-65 yaş grubundaki ev hanımlarının aktif ulaşım için harcadıkları enerji, 26-35 ve 36-45 yaş gruplarındaki ev hanımlarının harcadıklarından anlamlı düzeyde düşüktür $(\mathrm{p}<0.05)$. Ev aktiviteleri için harcanan enerji bakımından 18-25 
yaş grubundaki ev hanımlarının 26-35, 36-45 ve 46-65 yaş gruplarındaki ev hanımlarından, 26-35 yaş grubundaki ev hanımlarının 36-45 yaş grubundaki ev hanımlarından, 46-65 yaş grubundaki ev hanımlarının ise 26-35 ve 36-45 yaş gruplarındaki ev hanımlarından anlamlı düzeyde düşük olduğu belirlenmiştir $(\mathrm{p}<0.05)$. Hem 18-25 yaş grubundaki ev hanımlarının hem de 26-35 yaş grubundaki ev hanımlarının serbest zaman için harcadıkları enerji, 36-45 ve 46-65 yaş gruplarındaki ev hanımlarının harcadıkları enerjiden fazladır $(\mathrm{p}<0.05)$. Üniversite mezunu olan ev hanımlarının ev aktiviteleri için harcadığı enerji ilk ve ortaokul mezunları ve lise mezunlarının harcadığından daha az ( $\mathrm{p}<0.05)$, üniversite mezunlarının serbest zaman aktivitesi için harcadığı enerji hem ilk ve ortaokul hem de lise mezunlarının harcadığından daha fazla, lise mezunlarının harcadığı enerji ilk ve ortaokul mezunlarından fazla bulunmuştur $(p<0.05)$. Evli ev hanımlarının ev aktiviteleri için harcadıkları enerji bekar ev hanımlarının harcadıklarından anlamlı düzeyde fazla $(\mathrm{p}<0.05)$, bekar ev hanımlarının da serbest zaman aktiviteleri için harcadıkları enerji evli ev hanımlarından anlamlı düzeyde fazladır $(\mathrm{p}<0.05)$. Orta ve ortanın altında gelir düzeyine sahip ev hanımlarının ev aktiviteleri için harcadıkları enerji gelir düzeyi yüksek olanlardan daha fazla, serbest zaman aktiviteleri için harcadıkları enerji ise yüksek gelir düzeyine sahip ev hanımlarından daha az bulunmuştur $(\mathrm{p}<0.05)$.

Evli ev hanımlarının oturma süresi bekar ev hanımlarından daha uzun $(\mathrm{p}<0.05)$, ilk ve ortaokul mezunu ev hanımlarının oturma süresi, lise ve ünivesite mezunlarından daha uzun bulunmuştur $(\mathrm{p}<0.05)$. Yaş grupları açısından incelendiğinde 46-65 yaş grubundaki ev hanımlarının haftalık oturma süresi, diğer yaş gruplarındakilerden daha fazladır $(\mathrm{p}<0.05)$.

Ev hanımlarının günlük ortalama adım sayılarının yaş, medeni durum, eğitim ve gelir düzeyine göre karşılaştırılması Tablo 5'te gösterilmiştir.

Tablo 5. Ev hanımlarının günlük ortalama adım sayılarının medeni durum, gelir düzeyi, eğitim düzeyi ve yaş gruplarına göre karşılaştırılması.

\begin{tabular}{|c|c|c|c|c|c|c|c|}
\hline \multirow{2}{*}{\multicolumn{2}{|c|}{ Değişkenler }} & \multicolumn{3}{|c|}{ Adım sayısı (adım/gün) } & \multirow[b]{2}{*}{$\mathbf{t}$} & \multirow[b]{2}{*}{ Sd } & \multirow[b]{2}{*}{$\mathbf{p}$} \\
\hline & & $\mathbf{n}$ & Ort & Ss & & & \\
\hline \multirow{2}{*}{$\begin{array}{l}\text { Medeni } \\
\text { Durum }\end{array}$} & Evli & 40 & 12442.17 & 2912.89 & \multirow{2}{*}{1.529} & \multirow{2}{*}{58} & \multirow{2}{*}{0.132} \\
\hline & Bekar & 20 & 11287.80 & 2402.92 & & & \\
\hline \multirow{3}{*}{ Gelir Düzeyi } & Orta ve Alt1 & 40 & 11978.40 & 2915.84 & \multirow[b]{2}{*}{0.308} & \multirow[b]{2}{*}{58} & \multirow[b]{2}{*}{0.759} \\
\hline & Yüksek & 20 & 12215.35 & 2575.75 & & & \\
\hline & & & & & $\mathbf{F}$ & Sd & $\mathbf{p}$ \\
\hline \multirow{3}{*}{$\begin{array}{l}\text { Eğitim } \\
\text { Düzeyi }\end{array}$} & İlk ve Ortaokul & 29 & 12191.17 & 2794.28 & \multirow{3}{*}{2.651} & \multirow{3}{*}{2} & \multirow{3}{*}{0.079} \\
\hline & Lise & 20 & 12753.30 & 2924.88 & & & \\
\hline & Üniversite & 11 & 10439.36 & 1954.89 & & & \\
\hline \multirow{4}{*}{ Yaş } & $18-25$ & 5 & 9664.60 & 2096.53 & \multirow{4}{*}{1.597} & \multirow{4}{*}{3} & \multirow{4}{*}{0.200} \\
\hline & $26-35$ & 20 & 12384.60 & 2706.82 & & & \\
\hline & $36-45$ & 19 & 15541.84 & 2678.33 & & & \\
\hline & $46-65$ & 16 & 11820.81 & 3014.94 & & & \\
\hline Toplam & & 60 & 12057.38 & 2787.34 & & & \\
\hline
\end{tabular}

Ev hanımlarının günlük ortalama adım sayılarında yaş, medeni durum, eğitim ve gelir düzeyine göre anlamlı fark saptanmamıştır ( $>0.05)$. Adım sayıları bakımından ele alındığında evli olanların günlük adım sayılarının bekarlardan yaklaşık 1150 adım kadar fazla, üniversite mezunu olanların günlük adım sayılarının ilk ve ortaokul ile lise mezunu olanlardan yaklaşık 1700-2300 adım kadar az ve 36-45 yaşları arasındaki ev hanımlarının günlük adım sayılarının diğer yaş gruplarından yaklaşık 3000-6000 adım kadar fazla olduğu ancak istatistiksel olarak anlamlı fark olmadığ $(p>0.05)$ belirlenmiştir (Tablo 5). 
Tudor-Locke ve Bassett (2004) tarafından yetişkin bireyler için günlük ortalama adım sayıları sınıflandırılmıştır. Bu sınıflandırmada kesim noktaları, adım sayısındaki artışa göre sedanter düzeyden yüksek düzeyde aktife doğru gidecek şekilde oluşturulmuştur. Bu çalışmada ev hanımlarının hiçbirinin “sedanter” düzeyde olmadığı, tamamının günde 5000 adım ve üzerinde adım attığı ve \%76.6'sının günde minimum 10.000 adım attığı saptanmıştır.

IPAQ Research Committe tarafindan 2005 yılında hazırlanan kılavuz doğrultusunda katılımcıların FA düzeyleri düşük, orta ve yüksek şeklinde sınıflandırılmıştır (IPAQ Research Commitee, 2005). UFAA-UF'den elde edilen sınıflamaya göre ev hanımlarının yaklaşık üçte biri (\%33.1) yüksek düzeyde, yaklaşık üçte ikisi (\% 64.6) orta düzeyde aktiftir. Düşük düzeyde aktif olan ev hanımlarının oranı sadece \%2.3'tür.

\section{TARTIŞMA}

$\mathrm{Bu}$ çalışmanın amacı ev hanımlarının farklı FA şiddetlerine ve alanlarına göre harcadıkları enerji, adım sayısı ve oturma sürelerinin bazı demografik değişkenlere göre incelenmesidir. Bu çalışmada FA alanlarından biri olan ev aktivitelerine harcanan toplam enerji (MET-dk/hafta) ve süre (dk/hafta), aktif ulaşım ve serbest zaman FA alanlarına harcanandan daha yüksek bulunmuş, orta şiddetli FA için haftada ortalama 455 dakika zaman harcandığı görülmüştür (Tablo 1). Bu sonuca göre ev hanımlarının orta şiddetli FA, yürüyüş ve yüksek şiddetli FA'ya kıyasla daha yüksektir (Tablo 1). Najdi ve diğ. (2011)'nin çalışmasına göre ev hanımlarının çoğu (\%72.2) orta-şiddetli fiziksel aktivite düzeyindedir. Buna ek olarak ev hanımlarının teknoloji kullanımı çalışan kadınlardan daha düşük, ev aktiviteleri ise daha yüksektir (Talaei ve diğ., 2013). Buradan hareketle bizim çalışmamızda ev aktiviteleri için harcanan toplam enerji (MET$\mathrm{dk} / \mathrm{hafta}$ ) ve sürenin diğer FA alanlarından daha yüksek olması açısından literatürle benzerlik gösterdiği söylenebilir. Ayrıca bu çalışmada ev hanımlarının günlük ortalama adım sayıları 12057 iken (Tablo 5), Bassett ve diğ. (2010)'nin çalışmasında Amerika'da yaşayan kadınların gün içinde ortalama adım sayısı 4912'dir. Yetişkinler gün içindeki adım sayılarının çoğunu iş, ev içi ve serbest zaman aktivite alanlarında atmaktadırlar (Bassett ve diğ., 2008). Bu açıdan bakıldığında ev hanımlarının günün önemli kısmını evde geçiriyor olmaları ve ev içi aktivite düzeylerinin yüksek olması, günlük adım sayılarının arışını beraberinde getirebilir. Dolayısıyla bu çalışmadan elde edilen günlük ortalama adım sayısının yüksekliği, ev hanımlarının FA alanlarından olan ev aktivitelerinin artışına dayandırılabilir.

Bu çalışmada evli olan ev hanımlarının orta şiddetli FA (Tablo 2) ve ev aktivitelerine harcadıkları enerji bekar ev hanımlarından daha yüksek bulunmuştur (Tablo 3). Da Silva ve diğ. (2013)'nin çalışmasında eş zamanlı olarak hem aileden hem de arkadaştan sosyal destek alan bireylerin FA düzeyi akranlarından üç kat fazladır. Buradan yola çıkarak Marques ve diğ. (2016) evde daha fazla sayıda bireyin bulunmasının önerilen FA düzeyine ulaşma ile ilişkili olduğunu belirtmişlerdir. Ayrıca Shibata ve diğ. (2009) evli kadınların bekar kadınlara göre önerilen FA'ya ulaşma olasılığını 1.41 kat daha fazla bulmuşlardır. Bu bağlamda bazı ülkelerde yalnız yaşayan kadınların özellikle FA'ya katılımında önemli bir etkiye sahip olan yaşam standartları açısından dezavantajlı olduğu söylenebilir (Da Silva ve diğ., 2013). Buna ek olarak evli kadınların ev işlerine ayırdıkları zamanın daha çok olması ve bazı evli kadınların çocuklarına karşı olan sorumluluğu, çocuklarının okula gidip gelmesinde onlara eşlik etmeleri ve daha fazla ev alışverişine çıkmaları neticesinde FA düzeylerinde artış görülebilmektedir (Bulgu ve diğ., 2007). Ancak Puciato (2019)'nun kadın ve erkek yetişkinler üzerinde yaptıkları çalışmada evli olmayan kadınların evli olan kadınlara göre daha yüksek FA düzeyine ulaştıkları ve Amerikan Spor Hekimliği Koleji'nin FA önerilerini karşılama yüzdesinin daha yüksek olduğu belirtilmiştir. Puciato'nun çalışmasına benzer olan Basset ve diğg. (2010)'nin çalışmasında da bekar bireylerin evli bireylere kıyasla daha yüksek FA düzeyine sahip oldukları bulunmuştur. Dolayısıyla yalnız yaşayan bireylerde daha yüksek FA'ya ulaşılması fiziksel egzersize ayırdıkları serbest zamanlarının daha fazla olmasına dayandırılmaktadır (Puciato, 2019). Bu çalışmada, serbest zamanda 
elde edilen FA düzeyi bakımından bekar kadınlar evli kadınlardan fiziksel olarak daha aktif (Tablo 3), evli kadınların oturma süresi bekar kadınlardan daha uzun bulunmuştur (Tablo 4). Bu bağlamda evli kadınlarda çocuk bakma, ev işleri ve alışverişinin yapılması gibi artan sorumluluklar (Holtermann ve diğ., 2012), serbest zamanlarının azalmasına neden olurken, ev aktivitelerinde FA düzeyinin artışına yol açabilmektedir. Bu durum evli kadınların serbest zamanlarında FA'ya ayırdıkları süreyi azaltabilmektedir.

Bu çalışmada lise ve üniversite mezunu olanların yüksek şiddetli FA'lar için harcadıkları enerji, ilkokul ve ortaokul mezunlarına kıyasla daha yüksek bulunmuştur (Tablo 2). Ayrıca üniversite mezunlarının serbest zaman FA'ları için harcadıkları enerjinin diğer eğitim düzeyindeki ev hanımlarından yüksek (Tablo 3), ilk ve ortaokul mezunlarının ise oturma sürelerinin diğer eğitim düzeyine sahip olan ev hanımlarının oturma sürelerinden daha uzun olduğu saptanmıştır (Tablo 4). Gelişmekte olan ülkelerde, serbest zaman FA düzeyinin genel olarak eğitim düzeyinin ve gelir düzeyinin yükselmesiyle birlikte arttığı belirtilmektedir. Kuzey Avrupa'daki kesitsel çalışmalara göre, eğitim düzeyinin yükselmesi kadınlarda serbest zaman aktivitesinin güçlü ve tutarlı bir göstergesidir (Bauman ve diğ., 2011). Eğitimin sağlı üzerine etkisine bakıldığında, daha eğitimli kişilerin FA'yı teşvik eden kaynaklara erişiminde ve bilgiyi edinmede daha yetkin yaşam becerilerine sahip oldukları görülmektedir (Cusatis ve Garbaski, 2019). Ayrıca kentleşmiş ve eğitimli nüfusun "serbest zaman fiziksel aktivitesini” teşvik eden kamu sağlık kampanyalarına yanıt verme olasılığının daha yüksek olması, eğitim düzeyi ile ilişkili olarak FA düzeyini etkileyebilmektedir (Bauman ve diğ., 2011). Celis-Morales ve diğ. (2016)'nin çalışmasında eğitim düzeyi düşük olan kadınların fiziksel inaktivite prevelansı daha yüksek, serbest zamana ait orta şiddetli FA prevelansı daha düşük bulunmuştur. Buna ek olarak Wallmann-Sperlich ve Froboese (2014)'nin yetişkinler üzerinde yaptıkları çalışmada eğitim düzeyi yüksek olan bireylerin serbest zamanlarında orta-şiddetli FA'lar (MET-dk/hafta) için harcadığı enerji, eğitim düzeyi düşük olanlara kıyasla daha yüksek bulunmuştur. Dolayısıyla bu çalışmada da eğitim düzeyi yüksek olan kadınlarda şiddetli FA'lar ve serbest zaman FA'ları için harcanan enerjinin daha yüksek çıkması, literatürü destekler niteliktedir.

Wallmann-Sperlich ve Froboese (2014)'nin, Almanya'da yaptıkları çalışmada üniversite mezunu olanların ulaşım ve iş aktivitelerindeki orta-şiddetli FA'lara katılımı, 10 yıllık eğitimi tamamlamamış katılımcılardan daha düşük bulunmuştur. Buna ek olarak eğitim düzeyi düşük olan kadın ve erkeklerin, işyerinde orta şiddetli FA'lar için harcadıkları enerji miktarı (MET-dk/gün) yüksek eğitim düzeyinde olanlara kıyasla daha yüksektir (Celis-Morales ve diğ., 2016). Dolayısıyla özellikle ulaşım aktivitelerinde daha yüksek eğitim düzeyinde olan bireyler, yürümek veya toplu taşıma araçlarını tercih etmek yerine genellikle şahsi araçlarını kullanmaya daha fazla meyillidirler (Wallmann-Sperlich ve Froboese, 2014). Diğer yandan toplu taşıma araçlarının kullanımıyla beraber yürüme mesafesinin ve enerji harcamasının arttığı görülmektedir. Böylelikle eğitim düzeyi daha yüksek olanların gün içinde ulaşım aktivitelerine harcadıkları süre ve enerji daha düşük olabilmektedir. Ancak bu çalışmada aktif ulaşım için harcanan enerji bakımından eğitim durumları arasında farkın elde edilmemesinin nedeni (Tablo 3), ev hanımlarının çalışmıyor olmaları nedeniyle ulaşım aktivitelerinin belirli bir rutin içerisinde olmaması olabilir.

Eğitim düzeyi yüksek olan bireylerin fiziksel olarak şiddetli iş yükü gerektirmeyen mesleklerde çalışmaları nedeniyle iş aktiviteleri için harcadıkları enerji düşük olabilmektedir. Bu durum günlük FA düzeylerini nispeten azaltabilmektedir. Medina ve diğ. (2013) ve Hallal ve diğ. (2003)'nin yaptıkları çalışmalarda yüksek sosyo-ekonomik düzeyde olanların (\%46.6), düşük sosyo-ekonomik düzeyde olanlara (\%38.7) kıyasla fiziksel inaktivite prevelansının daha yüksek olduğunu ortaya koymuşlardır. Dolayısıyla literatürde kadınların gelir düzeyi veya sosyo-ekonomik düzeyleri bakımından fiziksel aktiviteye ilişkin farklı sonuçların elde edilmesi, sosyal örüntünün değişkenlik göstermesinin yanı sıra özellikle iş aktivitelerinde FA düzeyinin düşmesi (daha düşük gelir ve eğitim düzeyinde olanlarda genellikle daha düşük FA) ve 
rekreasyonel FA'nın artması (daha yüksek eğitim düzeyi ve gelir düzeyi olanlarda genellikle daha yüksek FA) ile karakterize edilmektedir (Celis-Morales ve diğ., 2016). Buradan hareketle bu çalışmada, ev hanımlarında orta şiddetli FA için harcanan enerji miktarı bakımından değerlendirildiğinde üniversiteden mezun olanlarda daha düşük değerlere ulaşılması (Tablo 2), literatürde ifade edilen gerekçelere dayandırılabilir ve literatürle benzerlik gösterdiğinden sözedilebilir.

Gerovasili ve diğg. (2015)'nin çalışmasında 28 Avrupa ülkesinde 18-64 yaşları arasındaki yetişkinlerin dörtte birinin fiziksel olarak inaktif olduğu belirtilmiştir. Literatürde genel olarak genç bireylerde yüksek FA düzeyi daha sık görüldüğü ve yaşla birlikte FA düzeyinin azaldığı belirtilmektedir (Puciato, 2019). Celis-Morales ve diğ. (2016), yaşla birlikte (sırasıyla, 18-24; 25-44; 45-64; > 65) harcanan toplam enerji (MET-dakika/gün), serbest zamanda orta-şiddetli FA'lar için harcanan enerji (MET-dakika/gün) ve ulaşım için harcanan enerjinin (MET-dakika/gün) kademeli bir şekilde azaldığını belirtmişlerdir. Bizim çalışmamızın oturma sürelerine bakıldığında en yüksek haftalık oturma süresi 46-65 yaş grubu kadınlara aittir (Tablo 4). Berksoy’un 2011 yılında yaptı̆̆ çalışmaya göre Ankara'da ikamet eden kadınlar arasında en fazla sedanter zaman geçirenler 40-55 yaş aralığındaki kadınlardır. Berksoy'un çalışmasına benzer şekilde mevcut bu çalışmada da 46 ve üzeri yaş grubu kadınların oturma süreleri diğer kadınlara göre daha uzundur (Tablo 4). Kadınların ileri yaşlarda fiziksel olarak daha inaktif bir yaşam sürme ve oturma sürelerinin yüksek çıkmasının nedeni olarak yaş ile birlikte ortaya çıkan kas ve eklem rahatsızlıkları ve bazı sağlık problemleri gösterilebilir (Kitiş ve Gümüş, 2015). Dolayısıyla kadınların yaş ilerledikçe kendilerini daha yorgun hissetmeleri ve serbest zamanlarını daha çok dinlenmek için değerlendirdikleri düşünülmektedir (Loland, 2004). Guthold ve diğ. (2008) tarafindan dünya genelinde 51 ülkede yapılan çalışmada yaş artışına bağlı olarak fiziksel inaktivite prevelansının arttığı vurgulanmaktadır. Ayrıca CelisMorales ve diğ. (2016)'ne göre fiziksel inaktivitenin yaşla birlikte değişkenlik göstermesinde emekli olma durumu belirleyici bir faktörtür. Bu çalışmada herhangi bir işte çalışmayan ev hanımlarının yer alması, yaş bakımından FA alanlarına göre emekliliğin belirleyici bir etken olmadığı düşünülebilir. Ancak önceden düşük bedensel hareketleri içeren işlerde (ofis ortamında çalışmak vb.) çalışıp emekli olan kadınların fiziksel olarak daha aktif olmayı gerektiren işlerde çalışıp emekli olan kadınlara göre serbest zamana ait FA düzeyleri daha düşüktür (Touvier ve diğ., 2010). Dolayısıyla kadınların geçmişte çalıştıkları iş ortamının emeklilikte FA alışkanlığını etkilemesi, yaşlı kadınların FA düzeyinin azalmasında kayda değer bir faktör olarak değerlendirilebilir. Bunun yanı sıra Moniruzzaman ve diğ. (2017) kadınlarda yaş arttıkça yeterli FA'ya ulaşamama eğiliminin arttığını belirtmektedirler. Orta yaş ve üstündeki kadınların çocuklarının kendi başına idare edebiliyor veya aileden bağımsız olarak yaşıyabiliyor olmaları ve ev işi görev ve sorumluluklarının daha az olması hem günlük hem de ev aktivitelerine harcanan enerjinin düşük olmasına neden olabilmektedir. Dolayısıyla literatürde, yaşın artışıyla birlikte FA düzeyinin azaldığı yönündeki bulgularla bu çalışmanın bulguları tutarlı değildir (Tablo 3). Marques ve diğ. (2016) 28 Avrupa ülkesinde, kadınlar üzerinde yaptıkları çalışmada yaşın (sırasıyla, 18-24; 25-34; 45-54; 55-64) artışı ile önerilen FA düzeyinin artışına dikkat çekmişlerdir. Bunun nedeni olarak, daha yaşlı olan bireylerin aile doktorlarına daha sık ziyaret ediyor olmaları ve bu ziyaretler sırasında doktorların günlük fiziksel aktivitenin önemine dair önerilerde bulunmaları olabilir (Marques ve diğ., 2016).

Can ve diğ. (2017) çalışan yetişkin kadınların hafta içi günde 10067 adım attıklarını ancak, cumartesi (9178 adım/gün) ve pazar günleri (7022 adım/gün) 10000 adım sayısına ulaşamadıklarını belirtmişlerdir. Bu çalışmada ise ev hanımlarının ortalama adım sayısı günde yaklaşık 2000 adım daha fazladır (Tablo 5). Tudor-Locke ve diğ. (2008)'nin çalışmasında 1839 yaş grubunun günde 9399 adım atığı ve günlük ortalama adım sayısınının yaş ilerledikçe azaldığı belirtilmiştir. Mevcut çalışmada ise en yüksek adım sayısına 36-45 yaş arası kadınların ulaştığı tespit edilmiştir (Tablo 5). Bu farklılıkların nedeni olarak ev hanımlarının yaş ilerledikçe sahip oldukları serbest zamanlarını daha çok fiziksel etkinliklere ayırdıkları, 
çalışan kadınların ise yaş ilerledikçe zamanlarını daha çok kariyerleri ile ilgili çalışmalar yaparak geçirdikleri şeklinde düşünülmektedir (Kim ve diğ., 2019).

Shibata ve diğ. (2009) kadınlarda ev içi gelirin artmasıyla önerilen FA düzeyine ulaşma olasıllı̆ının arttığını belirtmişlerdir. Araştırmacılar ev içi gelirini, FA gibi sağlık davranışlarının yaygınlaşmasında ve daha yüksek sosyoekonomik yapının sağlanmasında finansal özgürlüğü ve satın alma gücünü artıran anahtar bir mekanizma olarak belirtmektedirler (Cusatis ve Garbarski, 2019). Ayrıca serbest zaman FA alanında gelir düzeyinin önemi daha da artmaktadır. Örneğin; Cusatis ve Garbarski (2019)'nin çalışmasında ev içi geliri yüksek olan bireylerde (hem kadın hem de erkeklerde) serbest zaman FA düzeyleri daha yüksek bulunurken, ev içi geliri düşük olan bireylerde ise ev içi FA düzeyleri daha yüksek bulunmuştur. Wallmann-Sperlich ve Froboese (2014)'nin çalışmasında aylık ev içi geliri yüksek olan bireylerde serbest zamana ilişkin orta-şiddetli FA düzeyi daha yüksek, aylık ev içi geliri düşük olan bireylerde ise ulaşım aktivitelerine ilişkin orta-şiddetli FA düzeyi daha yüksektir. Bu çalışmada yüksek gelirli ev hanımlarının hem yüksek şiddetli FA (Tablo 2) hem de serbest zaman FA'ları için (Tablo 3) harcadıkları enerji, düşük gelirli ev hanımlarına göre daha fazladır. Ayrıca yüksek gelirli bireylerin ev aktiviteleri için harcadıkları enerjinin, düşük gelirli bireylerden daha az olduğu saptanmıştır (Tablo 3). Dolayısıyla bu sonuçların genel olarak literatürle uyumlu olmadığı söylenebilir. Bunun sebebi çalışmaya dahil edilen katılımcıların sadece ev hanımlarından oluşması olabilir. Çünkü ev hanımlarının kendi gelirlerinin olmaması ve gelirin aile giderlerine harcanmasından dolayı özellikle serbest zaman fiziksel aktiviteye ayırabilecekleri finansal kaynağı bulamamaları ve maliyet gerektiren yüksek şiddetli fiziksel aktiviteye katılamamaları olabilir. Diğer taraftan Marques ve diğ. (2016)'nin çalışmasında ev içi gelirinin yükselmesinin kadınların önerilen FA düzeyine ulaşılmasında etkili olmadığı belirtilmiştir. Dolayısıyla Marques'in çalışması daha yüksek gelir ve sosyoekonomik duruma sahip olan bireylerin çoğunlukla fiziksel olarak daha aktif olduklarını gösteren çalışmaları desteklememektedir. Zira yapılandırılmış FA için kullanışlı ve güvenli sokak ve mahallelerin olduğu, suç olaylarının görülmediği rekreatif ve yürüyüş alanlarının yaygınlaştırıldığı bölgelerde, gelir durumuna göre bireylerin fiziksel aktivite düzeyleri arasındaki fark azalmaktadır (Sugiyama ve diğ., 2014). Bu bağlamda fiziksel aktiviteyi artırmaya ilişkin yapılan eylem planlarının uygulandığı ülkelerde, gelir durumundan kaynaklı FA düzeyindeki değişim oranının muhtemelen azalma yönünde olacağı söylenebilir.

\section{SONUÇ}

Sonuç olarak; ev hanımlarının fiziksel aktivite yoluyla harcadıkları enerji, aktivite şiddetine göre incelendiğinde orta şiddetli fiziksel aktivitelerin, fiziksel aktivite alanı bakımından ise ev aktivitelerinin en büyük katkıyı sağladığı görülmüştür. Ayrıca ev hanımlarının neredeyse tamamı orta ve yüksek şiddette fiziksel aktivite düzeyini, dörtte üçü önerilen düzeyde adım sayısını karşılamaktadır.

\section{KAYNAKLAR}

1. American College of Sports Medicine (ACSM) (2018). Exercise is Medicine: ACSM's Prescription for Health, 21 Nisan 2020, https://www.acsm.org/read-research/newsroom/news-releases/news-detail/2018/05/02/exercise-is-medicine

2. Akdur H. (2003). Ev kadınlarının ve çalışan kadınların fiziksel aktive düzeylerinin araştırılması. İstanbul Üniversitesi Spor Bilimleri Dergisi, 11(3), 43-46.

3. Bassett DR, Pucher J, Buehler R, Thompson DL, Crouter SE. (2008). Walking, cycling, and obesity rates in Europe, North America, and Australia. Journal of Physical Activity and Health, 5(6), 795-814.

4. Bassett D, Wyatt H, Thompson H, Peters J, Hill J. (2010). Pedometer-measured physical activity and health behaviors in U.S. adults. Medicine and Science in Sports and Exercise, 42, 1819-1825. 
5. Bauman, A, Ma G, Cuevas F, Omar Z, Waqanivalu T, Phongsavan P, ve diğ. (2011). Cross-national comparisons of socioeconomic differences in the prevalence of leisure-time and occupational physical activity, and active commuting in six Asia-Pacific countries. Journal of Epidemiology \& Community Health, 65(1), 35-43.

6. Berksoy D. (2011). İzmir ve Ankara İllerinde Yaşayan Kadınların Fiziksel Aktivite Düzeylerini ve Beslenme Alışkanlıklarını Etkileyen Faktörlerin Karşılaştırılması. Doktora Tezi. Ankara Üniversitesi. Sağlık Bilimleri Enstitüsü Beden Eğitimi ve Spor Anabilim Dalı.

7. Biernat E, Piątkowska M. (2017). Leisure time physical activity among employed and unemployed women in Poland. Hong Kong Journal of Occupational Therapy, 29, 47-54.

8. Bulgu N, Koca Arıtan C, Aş̧ı FH. (2007). Gündelik yaşam, kadın ve fiziksel aktivite. Spor Bilimleri Dergisi, 18(4), 167-181.

9. Bullard T, Ji M, An R, Trinh L, Mackenzie M, Mullen SP. (2019). A systematic review and meta-analysis of adherence to physical activity interventions among three chronic conditions: cancer, cardiovascular disease, and diabetes. BMC Public Health, 19(1), 636.

10. Can S, Karaca A, Arslan E, Biernat E. (2017). Physical activity measurement by SWA in employees: weekdays and weekend. Physical Activity Review, 5, 167-175.

11. Çağlar, E, Karaca A, Şahin F, Gökalpgil M, Gürel S, Akkuş N. (2009). Fiziksel Aktivite Beslenme ve Sağlık Kongresi: Ev hanımlarının farklı düzeyde fiziksel aktivitelere katılım sürelerinin incelenmesi: Kırıkkale örneği. 95, 20-22 Kasım, Ankara.

12. Celis-Morales C, Salas C, Alduhishy A, Sanzana R, Martínez MA, Leiva A, ve diğ. (2016). Socio-demographic patterns of physical activity and sedentary behaviour in Chile: results from the National Health Survey 2009-2010. Journal of Public Health, 38(2), e98-e105.

13. Craig CL, Marshall AL, Sjorstrom M, Bauman AE, Booth ML, Ainsworth BE. (2003). International Physical Activity Questionnaire: 12-country reliability and validity. Medicine Science in Sports Exercise, 35(8), 1381-1395.

14. Cusatis R, Garbarski D. (2019). Different domains of physical activity: The role of leisure, housework/care work, and paid work in socioeconomic differences in reported physical activity. SSM-Population Health, 7, 100387.

15. Da Silva ICM, Azevedo MR, Gonçalves H. (2013). Leisure-time physical activity and social support among Brazilian adults. Journal of Physical Activity and Health, 10(6), 871-879.

16. Del Duca GF, Garcia LMT, Da Silva SG, Da Silva KS, Oliveira ES, Barros MV, ve diğ. (2015). Clustering of physical inactivity in leisure, work, commuting, and household domains: data from 47,477 industrial workers in Brazil. Journal of Physical Activity and Health, 12(9), 1264-1271.

17. Dünya Sağlık Örgütü (DSÖ) (2016). DSÖ Avrupa Bölgesi İ̧̧in Fiziksel Aktivite Stratejisi 2016-2025. 1 Şubat 2020, https://www.tatd.org.tr/files/files/fiziksel_aktivite.pdf

18. Gerovasili V, Agaku IT, Vardavas CI, Filippidis FT. (2015). Levels of physical activity among adults $18-64$ years old in 28 European countries. Preventive Medicine, 81, 87-91.

19. Guthold R, Ono T, Strong KL, Chatterji S, Morabia A. (2008). Worldwide variability in physical inactivity: a 51-country survey. American Journal of Preventive Medicine, 34(6), 486-494.

20. Hallal PC, Victora CG, Wells JCK, Lima RC. (2003). Physical inactivity: prevalence and associated variables in Brazilian adults. Medicine \& Science in Sports \& Exercise, 35(11), 1894-1900.

21. Holtermann A, Hansen J, Burr H, Søgaard K, Sjøgaard G. (2012). The health paradox of occupational and leisure-time physical activity. British Journal of Sports Medicine, 46(4), 291-295.

22. İnsani Gelişme Vakfı (İNGEV) (2017). İnsani Gelişme Endeksi İlçeler (İGE-İ) Raporu, Basın Bülteni, 26 Ocak 2017, İstanbul. http://ingev.org/wp-content/uploads/2017/10/IGE-I-ozet.pdf

23. IPAQ Research Committee. (2005). Guidelines For Data Processing and Analysis Of The International Physical Activity Questionnaire (IPAQ)-Short And Long Forms. 10Ocak2020, https://docs.google.com/viewer?a=v\&pid=sites\&srcid=ZGVmYXVsdGRvbWFpbnx0aGVpcGFxfGd4OjE0NDgxMDk3ND U1YWRIZTM

24. Kalkınma Bakanlığı. (2013). Onuncu Kalkinma Planı 2014-2018. Ankara. 1 Şubat 2020. http://www.sbb.gov.tr/wpcontent/uploads/2018/11/Onuncu-Kalkınma-Planı-2014-2018.pdf

25. Karaca A. (2008). Yetişkin bireylerde orta ve yüksek şiddetli fiziksel aktivitenin cinsiyete göre incelenmesi. Spor Bilimleri Dergisi, 19(1), 54-62.

26. Karaca, A. (2017). Fiziksel aktivite değerlendirme yöntemleri. Ankara: Spor Yayınevi.

27. Kim WK, Chung WC, Oh DJ. (2019). The effects of physical activity and sedentary time on the prevalence rate of metabolic syndrome and perceived stress in Korean adults. Journal of Exercise Rehabilitation, 15(1), 37.

28. Kim Y, Wijndaele K, Sharp SJ, Strain T, Pearce M, White T. (2019). Specific physical activities, sedentary behaviours and sleep as long-term predictors of accelerometer-measured physical activity in 91,648 adults: a prospective cohort study. International Journal of Behavioral Nutrition Physical Activity, 16(1), 41. 
29. Kirk MA, Rhodes RE. (2011). Occupation correlates of adults' participation in leisure-time physical activity: a systematic review. American Journal of Preventive Medicine, 40(4), 476-485.

30. Kitiş Y, Gümüş Y. (2015). 20 yaş ve üzeri kadınların fiziksel aktivite düzeyleri, fiziksel aktiviteye ilişkin inançları ve davranış aşamalarının belirlenmesi. Gümüşhane Üniversitesi Sağlık Bilimleri Dergisi, 4(3), 399-411.

31. Knuth AG, Hallal PC. (2009). Temporal trends in physical activity: a systematic review. Journal of Physical Activity and Health, 6(5), 548-559.

32. Loland NW. (2004). Exercise, health, and aging. Journal of Aging Physical Activity, 12(2), 170-184.

33. Marques A, Martins J, Peralta M, Catunda R, Nunes LS. (2016). European adults' physical activity socio-demographic correlates: a cross-sectional study from the European Social Survey. Peer J, 4, e2066.

34. Medina C, Janssen I, Campos I, Barquera S. (2013). Physical inactivity prevalence and trends among Mexican adults: results from the National Health and Nutrition Survey (ENSANUT) 2006 and 2012. BMC Public Health, 13(1), 1063.

35. Middlekauff M, Lee W, Egger MJ, Nygaard IE, Shaw JM. (2016). Physical activity patterns in healthy middle-aged women. Journal of Women \& Aging, 28(6), 469-476.

36. Milton K, Gale J, Stamatakis E, Bauman A. (2015). Trends in prolonged sitting time among European adults: 27 country analysis. Preventive medicine, 77, 11-16.

37. Moniruzzaman M, Ahmed MM, Zaman MM. (2017). Physical activity levels and associated socio-demographic factors in Bangladeshi adults: a cross-sectional study. BMC Public Health, 17(1), 59.

38. Najdi A, El Achhab Y, Nejjari C, Norat T, Zidouh A, El Rhazi K. (2011). Correlates of physical activity in Morocco. Preventive Medicine, 52(5), 355-357.

39. Öztürk M. (2005).Üniversitede Eğitim-Öğretim Gören Öğrencilerde Uluslararası Fiziksel Aktivite Anketinin Geçerliliği ve Güvenirliği ve Fiziksel Aktivite Düzeylerinin Belirlenmesi. Yüksek Lisans Tezi. Ankara: Hacettepe Üniversitesi. Sağlık Bilimleri Enstitüsü.

40. Peeters G, Van Gellecum YR, Van Uffelen JG, Burton NW, Brown WJ. (2014). Contribution of house and garden work to the association between physical activity and well-being in young, mid-aged and older women. British Journal of Sports Medicine, 48(12), 996-1001.

41. Puciato D. (2019). Sociodemographic Associations of physical activity in people of working age. International Journal of Environmental Research And Public Health, 16(12), 2134.

42. Sağlık Bakanlığı. (2013). Türkiye Kronik Hastalıklar ve Risk Faktörleri Sıklı̆̆ı Çalışması. Sağlık Bakanlığı Yayın No:909, Ankara, Anıl Matbaa. 1 Şubat 2020, https://sbu.saglik.gov.tr/Ekutuphane/Yayin/462

43. Santos-Lozano A, Santin-Medeiros F, Cardon G, Torres-Luque G, Bailon R, Bergmeir C, ve diğ. (2013). Actigraph GT3x: validation and determination of physical activity intensity cut points. International Journal of Sports Medicine, 34 (11), 975-982.

44. Shibata A, Oka K, Nakamura Y, Muraoka I. (2009). Prevalence and demographic correlates of meeting the physical activity recommendation among Japanese adults. Journal of Physical Activity and Health, 6(1), 24-32.

45. Stamatakis E, Ekelund U, Ding D, Hamer M, Bauman AE, Lee IM. (2019). Is the time right for quantitative public health guidelines on sitting? A narrative review of sedentary behaviour research paradigms and findings. British Journal of Sports Medicine, 53(6), 377-382.

46. Streb AR, Matias TS, Leonel LS, Tozetto WR, Vieira CG, Del Duca GF. (2019). Association between physical inactivity in leisure, work, commuting, and household domains and nutritional status in adults in the capital cities of Brazil. Revista de Nutrição, 32.

47. Sugiyama T, Cerin E, Owen N, Oyeyemi AL, Conway TL, Van Dyck D, ve diğ. (2014). Perceived neighbourhood environmental attributes associated with adults' recreational walking: IPEN Adult study in 12 countries. Health \& place, 28, 22-30.

48. Şeker M, Bakış Ç, Dizenci B. (2018). İnsani Gelişme Endeksi-İlçeler (İGE-İ) 2017 Tüketiciden İnsana Geçiş. İstanbul, İNGEV. Sertifika No:34794, Yayın no: 3.

49. Talaei M, Rabiei K, Talaei Z, Amiri N, Zolfaghari B, Kabiri P, ve diğ. (2013). Physical activity, sex, and socioeconomic status: A population based study. ARYA Atherosclerosis, 9(1), 51.

50. Touvier M, Bertrais S, Charreire H, Vergnaud AC, Hercberg S, Oppert, JM. (2010). Changes in leisure-time physical activity and sedentary behaviour at retirement: a prospective study in middle-aged French subjects. International Journal of Behavioral Nutrition and Physical Activity, 7(1), 14.

51. Treuth MS, Hou N, Young DR, Maynard LM. (2005). Validity and reliability of the Fels physical activity questionnaire for children. Medicine and Science in Sports and Exercise, 37(3), 488-495.

52. Trost SG, Owen N, Bauman AE, Sallis JF, Brown W. (2002). Correlates of adults' participation in physical activity: review and update. Medicine \& Science in Sports \& Exercise, 34(12), 1996-2001.

53. Tudor-Locke C, Bassett DR, Rutherford W, Ainsworth B, Chan C, Croteau K. (2008). BMI-referenced cut points for pedometerdetermined steps per day in adults. Journal of Physical Activity Health, 5(1), 126-139.

54. Tudor-Locke C, Bassett DR. (2004). How many steps/day are enough? Sports Medicine, 34(1), 1-8.

http://www.sbd.hacettepe.edu.tr 
55. Tudor-Locke C, Craig CL, Brown WJ, Clemes SA, De Cocker K, Giles-Corti B, ve diğ. (2011). How many steps/day are enough? For adults. International Journal of Behavioral Nutrition and Physical Activity, 8(1), 79.

56. Türkiye Cumhuriyeti Cumhurbaşkanlığı Strateji ve Bütçe Başkanlığı (SBB) (2019). On birinci Kalkinma Planı (2019-2023), 1 Şubat 2020, http://www.sbb.gov.tr/wp-content/uploads/2019/07/OnbirinciKalkinmaPlani.pdf

57. Wallmann-Sperlich B, Froboese I. (2014). Physical activity during work, transport and leisure in Germany-prevalence and sociodemographic correlates. PloS One, 9(11).

58. World Health Organisation (WHO). (2004). Global Strategy on Diet, Physical Activity and Health: Physical Activity, ISBN: 9241592222 , 20 Ocak 2020, https://www.who.int/dietphysicalactivity/strategy/eb11344/strategy_english_web.pdf

59. World Health Organization (WHO) (2010). Global recommendations on physical activity for health, 20 Ocak 2020 , https://apps.who.int/iris/bitstream/handle/10665/44399/9789241599979_eng.pdf?sequence=1

60. World Health Organization (WHO) (2018). Global action plan on physical activity 2018-2030: more active people for a healthier world. Geneva:World Health Organization; Licence: CC $\quad$ BY-NC-SA $3.0 \quad$ IGO. 23 Ocak 2020 , https://apps.who.int/iris/bitstream/handle/10665/272722/9789241514187-eng.pdf

61. World Health Organisation (WHO). (2020). Global Strategy on Diet, Physical Activity and Health: Physical Activity, 20 Ocak 2020 , https://www.who.int/dietphysicalactivity/pa/en/. 